\title{
QUANTITATIVE EVALUATION OF ENTERPRISE MARKETING ACTIVITIES
}

\author{
Romualdas Ginevičius $^{1}$, Valentinas Podvezko ${ }^{2}$, Adomas Ginevičius ${ }^{3}$ \\ Vilnius Gediminas Technical University, Sauletekio al.11, 10223 Vilnius, Lithuania \\ E-mails: ${ }^{1}$ romualdas.ginevicius@vgtu.lt (corresponding author); \\ ${ }^{2}$ valentinas.podvezko@vgtu.lt; ${ }^{3} v v f i e v k @ v g t u . l t$
}

Received 26 May 2012; accepted 09 August 2012

\begin{abstract}
The growing competition on the international markets means that the importance of enterprise marketing activities is increasing. However, the attention paid to theoretical and practical marketing problems by enterprises is insufficient. This particularly refers to the analysis of marketing strategy effectiveness. It is not clear how marketing affects enterprise performance. To perform this analysis, the quantitative evaluation of enterprise marketing activities is required. Enterprise marketing is a complex multi-faceted phenomenon. Its various aspects are described by multidimensional and often oppositely directed criteria. Therefore, in this case, multicriteria evaluation methods can be successfully used for analysis. The state of the enterprise marketing system is described by sets of criteria. Therefore, the problem of adequate evaluation of their weights arises. Sometimes, it is possible to reduce the number of evaluation criteria by developing their hierarchical system. However, the question arises how the transformation of a single-level system of criteria into the respective multi-level system affects the calculation results.
\end{abstract}

Keywords: enterprise marketing, hierarchical system, MCDM.

Reference to this paper should be made as follows: Ginevičius, R.; Podvezko, V.; Ginevičius, A. 2013. Quantitative evaluation of enterprise marketing activities, Journal of Business Economics and Management 14(1): 200-212.

JEL Classification: C44, G32, D79, M31.

\section{Introduction}

The increasing globalization causes the increase of the competition among enterprises, which should pay more attention to the needs of the markets and the clients. From the perspective of enterprise performance it means the increase of the role of enterprise marketing strategies.

Despite the fact that an enterprise is a basic economic unit of a country, the problems of enterprise marketing are not given due attention both from theoretical and practical perspectives (Banyte et al. 2010). Therefore, the main principles of establishing marketing departments and services as well as their functions and areas of operation have not been clearly defined yet. The distribution of the functions among the staff members of these departments and services and the systems of their payment are also far from 
being perfect, etc. The main drawback is, however, the lack of analysis of the effect of the described issues on enterprise performance. Therefore, a theoretical and practical problem, associated with the need for comprehensive analysis of the conditions of successful operation of marketing departments, aimed at increasing their effectiveness, arises (Banyte et al. 2011; Ginevičius, R., Ginevičius, A. 2008; Ginevičius et al. 2008; Markovič et al. 2011; Čater et al. 2011; Rutkauskas et al. 2008; Nadiri, Tümer 2010). One of the major aspects of this problem solution is quantitative evaluation of enterprise marketing system's performance. This could help to determine the effectiveness of marketing expenses, to improve marketing strategies, etc. (Ginevičius, A. 2007; Rutkauskas, Ginevičius, A. 2011; Ginevičius et al. 2011).

Enterprise marketing is a complex multi-faceted phenomenon. To evaluate its performance quantitatively, various aspects should be formalized, which means that the criteria should be developed and integrated into one generalized quantity. This is not a trivial task because the criteria may be multidimensional and oppositely directed, which implies that the increasing values of some criteria may indicate that the situation is getting better, while the increase of the values of other criteria shows that the situation is worsening. To solve these problems, multicriteria evaluation methods, widely used in recent years, may be applied (Figueira et al. 2005; Ginevičius et al. 2012b; Zavadskas, Turskis 2011; Brauers et al. 2010; Brauers, Zavadskas 2012a, 2012b; Zavadskas et al. 2011; Kanapeckiene et al. 2011; Podvezko et al. 2010; Podvezko, Podviezko 2010).

A major stage of multicriteria evaluation of a complex phenomenon is the development of a set of criteria. If their number is small, a single-level set of criteria may be used because the experts can determine their weights sufficiently accurately. However, some problems arise, when the number of the criteria is large. To reduce this number, a hierarchical criteria system is developed, and the evaluation is made at each hierarchical level, beginning with the lowest level and finishing with the level of the considered phenomenon. In this case, the weights of the elements found at each level should be determined. The question arises about the effect produced on the calculation results by transforming a single-level set of criteria into a hierarchical multilevel set of criteria (Ginevičius, Podvezko 2007). All these problems are considered in the present article.

\section{Theoretical aspects of quantitative evaluation of enterprise marketing performance effectiveness}

Enterprise marketing may be analysed as a complex system because all enterprise departments are involved in its functioning. The analysis of such systems is aimed at determining the opportunities for purposeful changing of their performance, i.e. for ensuring their effective management (Ginevičius 2009). This can be achieved only if the performance of a system is quantitatively evaluated. So far, the efforts for its qualitative evaluation have been made. It was considered that the analysis of a system, its parts and their interrelations could be sufficient for its organization, managing and targeting (Jasinavičius 1981; Ginevičius 2009). However, it seems that the analysis of this kind can hardly help provide the conditions for the effective system management. If the 
performance of the system was slightly improved, we would have two (the past and the current) states of its good performance. However, it would not allow us to compare the costs of improving the system's performance and the extent of the improvement made. To achieve this, the above two states of the system should be quantitatively evaluated. Quantitative evaluation of marketing system's performance at an enterprise could help more thoroughly analyse this phenomenon by considering it from various perspectives (Ginevičius 2009).

The quantitative evaluation of the performance of a system requires that it should be described by a set of criteria (Ginevičius 2009). The selection of the criteria is not a trivial task because a marketing enterprise system is multifaceted. All these facets should be transformed to criteria. For this purpose, systems should be classified, i.e. grouped according to their general features. The analysis of the literature on the problem shows that there is a great number of various classifications. This variation can be explained by the fact that different system's characteristics are used for classification, e.g. the nature of the system, its management, the kind of relationships between the constituent elements, general system's characteristics, the relations with the target, complexity, changeability, implementation, the relations with the environment, mathematical models used for system's description, physical and other characteristics, organisation level, etc. This variety shows that each author, basing himself on a particular set of criteria, may offer a particular classification. Then, a question arises if a uniform, widely accepted classification is needed, or the current situation with a great variety of classifications is quite satisfying. The answer depends on the targets of the systems' classification. Everything, associated with the systems' analysis, is aimed at getting a deeper insight into them for achieving their better management. Since the considered systems are large and complex, researchers have not developed a comprehensive methodology of their analysis. As a result, one of the important aspects, such as size, target, nature, relations with the environment, etc. is usually taken for the analysis of the systems by a particular researcher according to his choice. Thus, the classification of the systems based on various characteristics provides the possibility to choose one, which is most suitable from the considered problem perspective.

In the present investigation, the classification is made into real (material) and theoretical (abstract) systems. The first ones are the phenomena of inorganic nature (physical, geological, chemical, etc.), while biological, social, economic and other systems of the second group are natural. Theoretical (abstract) systems include hypotheses, theories, formalized models, etc. In other words, they present the information and knowledge about the possibilities and methods of reflecting real (material) systems.

The above classification of the considered systems is relevant for evaluation of their performance (state). This becomes evident, when the relations between the real (material) and theoretical (abstract) systems are considered. In fact, the latter are derived from the former, which means that theoretical (abstract) systems are, as mentioned above, intended for reflecting real (material) systems (Ginevičius 2009). Theoretical (abstract) systems, according to their nature, are formalized real (material) systems' models. 
The marketing activities of an enterprise are referred to socioeconomic systems because they integrate some materials, tools, information, etc., as well as such social elements as people. Therefore, they are large and complicated systems, which can be perceived through the study of their various aspects and attributes. It follows that the criteria interrelated as the system's elements, describing these aspects in a theoretical (abstract) model, reflect real (material) systems (Ginevičius 2006, 2007b). A more thorough analysis shows that this relationship is not so simple and depends on the size of the system. When a system is small and, therefore, less complicated, a few criteria, directly interrelated and reflecting some particular system's aspects, may be used to describe it (Ginevičius 2007b). The situation, however, is different with large systems. Their performance is described by a great number of criteria, while their interrelations or the reflection of some particular system's aspects may be indirect. Sometimes, it is hardly possible to determine all these relationships or the reflection of the system's aspects. A good example is economic and social development of the state regions, which is described by about 200 criteria (Counties of Lithuania... 2009). Some of these criteria are hardly comparable. For example, crime, birth rate, area under crops, etc. Moreover, it is hardly possible to determine their effect on the economic and social development of a region (Brauers et al. 2010; Ginevičius, Podvezko 2007, 2008). Therefore, it may be concluded that it is very difficult to determine the interrelationship between the criteria describing large complicated systems and their mutual influence. Then, the question arises if this situation does not conflict with the theoretical statement that all elements of the system are interrelated. One more question is as follows: how is it possible to generate a set of criteria, reflecting system's performance?

To answer this question, the available definitions of a system should be considered. These definitions are plentiful, but we will rely on this one: a system is the structured whole of interacting elements (Ginevičius 2009). The concept of 'the whole' singles out a set of criteria from the environment, thereby delimiting the system, while the concept of 'structured' implies that the elements of the system are arranged hierarchically (in order of ranks), based on their interaction, which helps them to strive for the general aim of the system.

A socioeconomic system is large and complicated, therefore, the main goal is grouping the criteria describing its performance according to some particular characteristics, rather than searching for their interrelationships (Ginevičius 2007a). In other words, sets of criteria, reflecting various aspects of a system are formed. This step and the underlying logic follow the idea that the weaker a particular criterion reflects a particular aspect of a system, the further it is from it. It makes us believe that, in this case, the criterion is closer to another aspect, which it reflects. In the case, when it is not close to any system's aspect, it itself reflects some particular system's aspect.

Particular criteria, as well as their sets, do not reflect the performance of a system in the same way. It follows that a set of criteria, describing a complex system, e.g. a socioeconomic system, cannot be of the same level. Different significance of the sets of criteria leads to the formation of their hierarchical structure (Ginevičius 2007a). 
The arrangement of the criteria describing a socioeconomic system hierarchically helps to explain the mechanism of their interaction. The description of various system's aspects by particular criteria results in the situation, when the criteria belonging to the same set or group are directly interdependent, while the criteria of a set, describing another system's aspects are connected only indirectly via the values, aggregating the values of the criteria sets. The latter, in their turn, may be interrelated both directly and indirectly.

\section{Developing a set of criteria, describing enterprise marketing activities}

The development of a set of criteria, describing enterprise marketing activities, is based on the above considerations.

It is believed that a set of criteria is adequate, when all the included criteria reflect the essential aspects of the system. However, the set of criteria should be limited, otherwise, the evaluation could be imprecise or impossible due to a very large number of criteria. Enterprise marketing is described by ten criteria, which is too much for evaluation. It follows that the number of the criteria should be decreased. This may be achieved in several ways. The first way is to exclude some criteria from the set, leaving only the most significant ones. This may be performed by experts or by using the methods of mathematical statistics (Ginevičius et al. 2012a). However, in this case, a danger of excluding the essential criteria, thereby reducing the evaluation accuracy, arises. It is known that the reduction of the number of the criteria may be achieved by their integration with others, rather than by exclusion. In this way, the criteria will be more complex and more widely describe the particular system's aspects. However, new problems arise: the first one, associated with the accuracy of the evaluation of aggregated criterion significance and the second one, connected with accurate determination of the value of this type of criterion.

A different approach to reducing the number of simultaneously evaluated criteria is based on forming their hierarchical structure, based on the above-described principles. In this case, not only the levels of the above structure, but sets of the related criteria found at various levels, will be separately evaluated.

The analysis of the literature on the problem reveals various approaches to the model of marketing activities and functions. Some researchers suggest including four elements in it, such as product, price, promotion and place, while others offer seven elements, adding people, processes and physical properties to the already mentioned ones. There are also researchers, suggesting a three-element model, including clients, competitors and company, or a four-element, but different model, including clients, competitors, capacities and company. A five-element model, based on value, realization, volumes, variety and effectiveness, is also offered. In general, up to thirty elements are suggested to be included into the description of enterprise marketing activities. However, in most cases, the 4P marketing model (including product, price, promotion and place), successfully used by the most of production and service providing companies in Eastern Europe, is considered to be best-responding to the main business challenges (Goi 2009; Ginevičius et al. 2012a; Yudelson 1999). 
Now, it is necessary to determine the criteria, describing its elements taking the above 4P marketing model as a basis. The set of these criteria was defined, based on the analysis of the related works and expert evaluation. As a result, a hierarchical set of criteria, describing enterprise marketing activities, which is presented in Figure 1, was obtained.

\section{Multicriteria evaluation of enterprise marketing activities}

As shown in Figure 1, quantitative evaluation of enterprise marketing activities is based on the use of 27 criteria, grouped into 4 sets. To get a general view, all the criteria should be aggregated into a single value. This is not a simple task because, usually, the criteria are expressed in various dimensions. Moreover, they may change in opposite directions, implying that the increase of the values of some criteria means that the situation is getting better, while for other criteria it shows that the situation is getting worse. To solve these problems, multicriteria evaluation methods should be used.

Multicriteria evaluation is usually aimed at arranging the available alternatives in the order of preference (ranking). It helps, for example, to choose the best building construction project, to rank the state regions according to their economic and social development level, etc. Normalization methods of multidimensional criteria also serve this purpose. The normalized dimensionless criteria values can, for example, be obtained by dividing the $\mathrm{j}$-th criterion value by the sum of its values for all the alternatives of the considered object or phenomenon. In this case, the normalized value of the $j$-th criterion of a particular alternative is influenced by the same values of other alternatives. However, the task of the present investigation is quantitative evaluation of marketing activities of a particular enterprise. This should allow us to compare its expenses on quality improvement with the result obtained. The main problem to be solved is the normalization of multidimensional values, i.e. making them comparable.

The considered novel approach to multicriteria evaluation and the respective methodology, called AID, were developed and presented in Ginevičius (2008). The suggested methods were used in solving various problems (Ginevičius, A. 2011; Ginevičius et al. 2012c).

In the case considered in the present paper, the problem of multicriteria evaluation is simplified because all the criteria are expressed in the same dimension (points) and change in the same direction (see Fig. 1). This means that normalization is not even needed.

Another problem arising in quantitative evaluation of marketing activities is associated with the methods of using a hierarchical set of criteria for this purpose. In the case of evaluation based on a single-level set of criteria, experts should determine the weights of 27 criteria simultaneously. Taking into account that the sum of the weights is equal to unity, it is clear that it is hardly possible to determine the weights of the considered number of criteria accurately.

As mentioned above, rearranging a single-level set of criteria into a hierarchical structure helps to reduce the number of simultaneously evaluated criteria. As shown in Figure 1, the experts should make five evaluations of the criteria weights, including the elements 


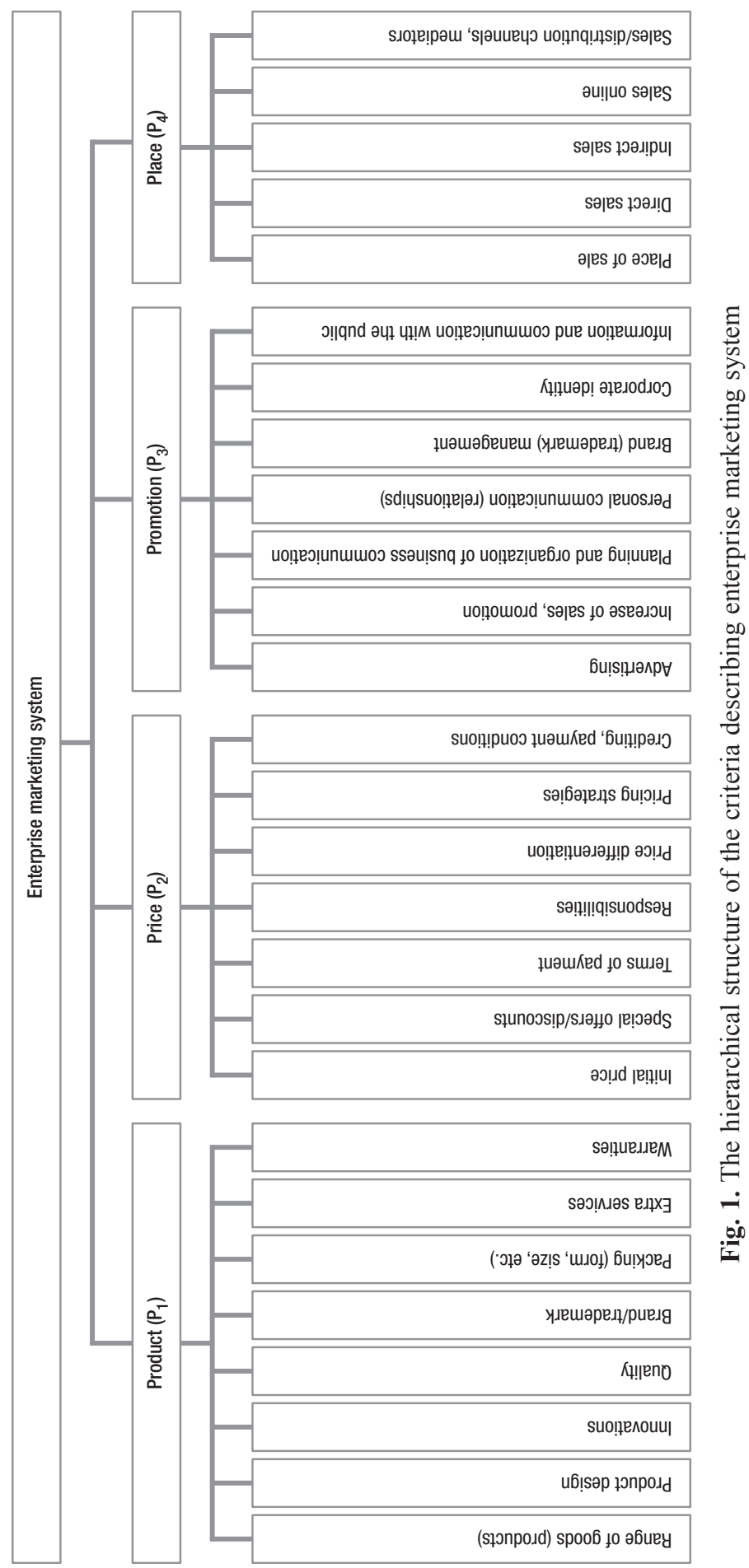


of a marketing mix (i.e. product, price, promotion and place) and the criteria describing them: 8 criteria of product, 7 criteria of price, 7 criteria of promotion and 5 criteria of place. As mentioned in the related works, experts can accurately evaluate the weights of about 12 criteria (Ginevičius, R. 2011). As shown in Figure 1, this condition is satisfied.

Since the weights of criteria are evaluated by experts, the consistency of their estimates should be checked. It is usually performed by using the concordance coefficient $\mathrm{W}$ and Pearson correlation coefficient $\chi^{2}$ (Kendall 1970; Podvezko 2007). The results obtained by determining the consistency of experts' judgements are presented in Table 1.

Table 1. The verification results of the consistency of the criteria weights of the marketing mix elements elicited from experts

\begin{tabular}{llcccc}
\hline & Marketing & \multicolumn{4}{c}{ Criteria } \\
\cline { 3 - 6 } No & $\begin{array}{c}\text { mix } \\
\text { component }\end{array}$ & $\begin{array}{c}\text { Sum of squared } \\
\text { deviations from } \\
\text { the overall mean }\end{array}$ & $\begin{array}{c}\text { Concordance } \\
\text { coefficient } \mathrm{W}\end{array}$ & $\chi^{2}$ & $\begin{array}{c}\text { Critical } \chi^{2} \text { value with } v=7,6, \\
\text { and } 4 \text { degrees of freedom and } \\
\text { significance level } \alpha=0.05\end{array}$ \\
\hline 1. & Product & 3008 & 0.592 & 45.58 & 14.07 \\
\hline 2. & Price & 1828.9 & 0.540 & 35.63 & 12.59 \\
\hline 3. & Promotion & 2486.3 & 0.734 & 48.45 & 12.59 \\
\hline 4. & Place & 1505.9 & 0.711 & 39.10 & 11.07 \\
\hline
\end{tabular}

As shown in Table 1, experts' judgements are consistent in all four cases.

In the same way, the consistency of the experts' estimates of the weights of the criteria, describing the marketing mix elements, was checked. The evaluation results of the weights of all hierarchical system's elements given in Figure 1 are shown in Table 2.

The values of the criteria presented in Table 2 were determined by experts against the 100-point scale. The mean values of all experts' estimates were taken for further calculation, when their consistency had been determined.

Given the weights and the values of both the elements of the marketing mix and the criteria describing them, multicriteria evaluation of the effectiveness of enterprise marketing activities may be performed. This was made by using the method SAW (Podvezko 2011) as follows:

$$
K=\sum_{i=1}^{n} w_{i} K_{i},
$$

where $K$ is the value obtained in multicriteria evaluation of the marketing mix; $w_{i}$ is the weight of the $i$-th marketing mix element; $K_{i}$ is the value of the $i$-th marketing mix element.

Multicriteria evaluation of the i-th marketing mix element was performed as follows:

$$
K_{i}=\sum_{k=1}^{n_{i}} w_{i k} r_{i k},
$$

where $w_{i k}$ is the weight of the $k$-th criterion of the $i$-th marketing mix element; $r_{i k}$ is the value of the $k$-th criterion.

The results of this evaluation are given in Table 3 . 
Table 2. Weights of the components of enterprise marketing system described by the hierarchical set of criteria

\begin{tabular}{|c|c|c|c|}
\hline $\begin{array}{l}\text { Marketing } \\
\text { mix } \\
\text { component }\end{array}$ & $\begin{array}{l}\text { Weights of the } \\
\text { marketing mix } \\
\text { component }\end{array}$ & Criteria & $\begin{array}{l}\text { Weights } \\
\text { of the } \\
\text { components }\end{array}$ \\
\hline \multirow{9}{*}{$\begin{array}{l}\text { Product } \\
\left(\mathrm{P}_{1}\right)\end{array}$} & \multirow{9}{*}{0.282} & 1.Range of goods (products) & 0.110 \\
\hline & & 2.Product design & 0.113 \\
\hline & & 3.Innovations & 0.128 \\
\hline & & 4.Quality & 0.200 \\
\hline & & 5.Brand/trademark & 0.142 \\
\hline & & 6.Packing (form, size, etc.) & 0.079 \\
\hline & & 7.Extra services & 0.091 \\
\hline & & 8. Warranties & 0.136 \\
\hline & & Total & 1.00 \\
\hline \multirow{8}{*}{$\begin{array}{l}\text { Price } \\
\left(\mathrm{P}_{2}\right)\end{array}$} & \multirow{8}{*}{0.240} & Initial price & 0.187 \\
\hline & & Special offers/discounts & 0.182 \\
\hline & & Terms of payment & 0.100 \\
\hline & & Responsibilities & 0.150 \\
\hline & & Price differentiation & 0.130 \\
\hline & & Pricing strategies & 0.117 \\
\hline & & Crediting, payment conditions & 0.132 \\
\hline & & Total & 1.00 \\
\hline \multirow{8}{*}{$\begin{array}{l}\text { Promotion } \\
\left(\mathrm{P}_{3}\right)\end{array}$} & \multirow{8}{*}{0.223} & Advertising & 0.178 \\
\hline & & Increase of sales, promotion & 0.169 \\
\hline & & $\begin{array}{l}\text { Planning and organisation of business } \\
\text { communication }\end{array}$ & 0.129 \\
\hline & & Personal communication (relationships) & 0.150 \\
\hline & & Brand (trademark) management & 0.129 \\
\hline & & Corporate identity & 0.134 \\
\hline & & Information and communication with the public & 0.111 \\
\hline & & Total & 1.00 \\
\hline \multirow{5}{*}{$\begin{array}{l}\text { Place } \\
\left(\mathrm{P}_{4}\right)\end{array}$} & \multirow{5}{*}{0.255} & Place of sales & 0.223 \\
\hline & & Direct sales & 0.234 \\
\hline & & Indirect sales & 0.166 \\
\hline & & Sales online & 0.138 \\
\hline & & Sales/distribution channels, mediators & 0.229 \\
\hline Total & 1.00 & Total & 1.00 \\
\hline
\end{tabular}


Table 3. The result of the multicriteria evaluation of marketing activity of an enterprise

\begin{tabular}{lc}
\hline \multicolumn{1}{c}{ The Object of the Evaluation } & The Result of the Multicriteria Evaluation \\
\hline Marketing mix component: & 61.73 \\
product & 64.58 \\
price & 63.72 \\
promotion & 59.53 \\
place & 62.30 \\
\hline Enterprise &
\end{tabular}

As shown in Table 3, the highest estimate value is given to product. Then follow promotion, product and place.

\section{The effect of the structure of the criteria set describing enterprise marketing activities on multicriteria evaluation results}

As mentioned above, until now, multicriteria evaluation has been based on a singlelevel, i.e. non-structured set of criteria. In this paper, multicriteria evaluation relies on a hierarchically structured set of criteria. The question arises about the influence of the structure of the criteria set on the results obtained in multicriteria evaluation. To answer this question, some additional multicriteria evaluation, based on the formula given below, was performed:

$$
K=\sum_{i=1}^{n} w_{i} r_{i},
$$

where $K$ is the value obtained in multicriteria evaluation of enterprise marketing activities, when the criteria set is non-structured; $w_{\mathrm{i}}$ is the weight of the $i$-th enterprise marketing mix; $r_{i}$ is its value.

As shown in formula 3 , the evaluation was based not on 27 criteria, describing various elements of the marketing mix, but the four elements themselves $(n=4)$. This was made because experts could not determine the weights of so many criteria.

The value obtained in multicriteria evaluation of four marketing system's elements is equal to 72.04. The value obtained in multicriteria evaluation based on the hierarchically structured set of criteria is equal to 62.3 .

Now, the results obtained in multicriteria evaluation based on a single-level and hierarchically structured sets of criteria may be compared. One can see that the difference makes about $10 \%$. Therefore, it may be assumed that more detailed classification of enterprise marketing aspects can help better describe its performance. It also follows that multicriteria evaluation based on hierarchically structured set of criteria is more accurate.

\section{Conclusions}

1. Since marketing activities of an enterprise are described by a large set of criteria, accurate evaluation of their weights presents some difficulties for experts. To solve this problem, the transformation of a single-level set of criteria into a hierarchical structure should be made. 
2. A set of criteria describing the performance (or state) of enterprise marketing system is based on four elements (the so-called 4P model), including product, price, promotion and place (distribution). Making a list of the criteria, describing each of these elements, a hierarchical system of the criteria describing marketing activities of an enterprise can be obtained.

The performed multicriteria evaluation of enterprise marketing activities, based on the use of both single- and multi-level (hierarchical) sets of criteria, yielded different results. The differences make about 10 per cent. It is reasonable to assume that more detailed classification of the criteria, describing enterprise marketing activities, which is aimed at developing their hierarchical system, helps to get a more clear view of the situation.

\section{References}

Banyte, J.; Brazioniene, L.; Gadeikiene, A. 2010. Expression of green marketing developing the conception of corporate social responsibility, Inzinerine Economika - Engineering Economics 21(5): 550-560.

Banyte, J.; Gudonaviciene, R.; Grubys, D. 2011. Changes in marketing channels formation, Inzinerine Economika - Engineering Economics 22(3): 319-329.

Brauers, W. K. M.; Ginevičius, R.; Podvezko, V. 2010. Regional development in Lithuania considering multiple-objective by the Moora method, Technological and Economic Development of Economy 16(4): 613-640. http://dx.doi.org/10.3846/tede.2010.38

Brauers, W. K. M.; Zavadskas, E. K. 2012a. A multi-objective decision support system for project selection with an application for the Tunisian textile industry, $E \& M$ Ekonomie a Management 15(1): 28-43.

Brauers, W. K. M.; Zavadskas, E. K. 2012b. Robustness of MULTIMOORA: a method for multiobjective optimization, Informatica 23(1): 1-25.

Counties of Lithuania. Economic and Social Development. 2009. Vilnius: Statistics Lithuania. ISSN 1648-0260.

Čater, B.; Žabkar, V.; Čater, T. 2011. Commitment in marketing research services: two alternative models, Journal of Business Economics and Management 12(4): 603-628.

http://dx.doi.org/10.3846/16111699.2011.599410

Figueira, J.; Greco, S.; Ehrgott, M. (Eds.). 2005. Multiple Criteria Decision Analysis: State of the Art Survey. Springer.

Ginevičius, R. 2006. Multicriteria evaluation of the criteria weights based on their interrelationship, Business: Theory and Practice 7(1): 3-13 (in Lithuanian).

Ginevičius, A. 2007. Quantitative evaluation of enterprise marketing effectiveness, Technological and Economic Development of Economy 13(1): 19-23.

Ginevičius, R. 2007a. Hierarchical structuring of processes and phenomena, Business: Theory and Practice 8(1): 14-18 (in Lithuanian).

Ginevičius, R. 2007b. Generating a structured system of criteria for describing a complicated phenomenon, Business: Theory and Practice 8(2): 68-72 (in Lithuanian).

Ginevičius, R. 2008. Normalization of quantities of various dimensions, Journal of Business Economics and Management 9(1): 79-86. http://dx.doi.org/10.3846/1611-1699.2008.9.79-86

Ginevičius, R. 2009. Some problems of quantitative evaluation of the state social-economic systems, Business: Theory and Practice 10(2): 69-83 (in Lithuanian).

Ginevičius, A. 2011. Increasing Economic Effectiveness of Marketing: Doctoral Dissertation. Vilnius: Technika. $145 \mathrm{p}$. 
Ginevičius, R. 2011. A new determining method for the criteria weights in multicriteria evaluation, International Journal of Information Technology \& Decision Making 10(6): 1067-1095. http://dx.doi.org/10.1142/S0219622011004713

Ginevičius, R.; Podvezko, V. 2007. Complex assessment of sustainable development of state regions with emphasis on ecological and dwelling conditions, Ekologija 53 (Supplement): 41-48.

Ginevičius, R.; Podvezko, V. 2008. Housing in the context of economic and social development of Lithuanian regions, Int. J. Environment and Pollution 35(2/3/4): 309-330.

Ginevičius, R.; Podvezko, V.; Podviezko, A. 2012c. Evaluation of isolated socio-economic processes by a multi-criteria decision aid method ESP, in Proc. of the $7^{\text {th }}$ International Scientific Conference on Business and Management'2012, 10-11 May 2012, Vilnius, Lithuania. Vilnius: Technika, 1083-1088.

Ginevičius, R.; Ginevičius, A. 2008. Sustainability decisions in marketing complex cost optimization process, in Proc. of the 12th World Multi-Conference on Systemics, Cybernetics and Informatics/14th International Conference on Information Systems Analysis and Synthesis, 29 June-02 July 2008, Orlando, Florida, USA. V1: /International Institute of Informatics and Systemics Orlando: IIIS, 35-40.

Ginevičius, A.; Ginevičienè, V.; Podvezko, V. 2008. The effectiveness of enterprise marketing system, in Conference Information of International Conference on Management and Marketing Sciences (ICMMS 2008), 23-25 May 2008, Athens, Greece. England: Imperial College Press,, 480-483.

Ginevičius, R.; Podvezko, V.; Ginevičius, A. 2011. Determining the significance of the criteria describing enterprise marketing, in Proc. of the 15th World Multi-Conference on Systemics (WMSCI 2011), Cybernetics and Informatics. 2011, Orlando, Florida, USA.1: /International Institute of Informatics and Systemics Orlando: IIIS, 88-93.

Ginevičius, R.; Podvezko, V.; Ginevičius, A. 2012a. Determining the effectiveness of enterprise marketing based on the 4P's model, in Proc. of the $7^{\text {th }}$ International Scientific Conference on Business and Management'2012, 10-11 May 2012, Vilnius, Lithuania. Vilnius: Technika, 366-372.

Ginevičius, R.; Podvezko, V.; Novotny, M.; Komka, A. 2012b. Comprehensive quantitative evaluation of the strategic potential of an enterprise, Economic Computation and Economic Cybernetics Studies and Research 46(1): 65-84.

Goi, C. L. 2009. A review of marketing mix: 4Ps or more?, International Journal of Marketing Studies 1(1): 2-15.

Jasinavičius, R. 1981. Systems Theory. Vilnius: Publishing house of the Ministry of Higher and Special Secondary Education of the Lithuanian SSR (in Lithuanian).

Kanapeckiene, L.; Kaklauskas, A.; Zavadskas, E. K.; Raslanas, S. 2011. Method and system for multi-attribute market value assessment in analysis of construction and retrofit projects, Expert Systems with Applications 38(11): 14196-14207.

Kendall, M. 1970. Rank Correlation Methods. $4^{\text {th }}$ ed. London: Griffin.

Markovič, D.; Grgurovič, B.; Štrbac, S. 2011. The use of spatial data for segmentation of the postal service market, Technological and Economic Development of Economy 17(1): 87-100. http://dx.doi.org/10.3846/13928619.2011.554016

Nadiri, H.; Tümer, M. 2010. Influence of ethnocentrism on consumer' intention to buy domestically produced goods: an empirical study in North Cyprus, Journal of Business Economics and Management 11(3): 444-461. http://dx.doi.org/10.3846/jbem.2010.22

Podvezko, V. 2007. Determining the level of agreement of expert estimates, International Journal of Management and Decision Making 8(5/6): 586-600.

http://dx.doi.org/10.1504/IJMDM.2007.013420

Podvezko, V. 2011. The comparative analysis of MCDA methods SAW and COPRAS, Inzinerine Ekonomika - Engineering Economics 22(2): 134-146. 
Podvezko, V.; Mitkus, S.; Trinkūnienè, E. 2010. Complex evaluation of contracts for construction, Journal of Civil Engineering and Management 16(2): 287-297.

http://dx.doi.org/10.3846/jcem.2010.33

Podvezko, V.; Podviezko, A. 2010. Dependence of multi-criteria evaluation result on choice of preference functions and their parameters, Technological and Economic Development of Economy 16(1): 143-158. http://dx.doi.org/10.3846/tede.2010.09

Rutkauskas, A. V.; Ginevičius, A. 2011. Integrated management of marketing risk and efficiency, Journal of Business Economics and Management 12(1): 5-23.

http://dx.doi.org/10.3846/16111699.2011.555357

Rutkauskas, A. V; Stasytytè, V.; Ginevičius, A. 2008. Three-dimensional measurement of market behavior, in Proc. of the $5^{\text {th }}$ International Scientific Conference on Business and Management'2008, 16-17 May 2008, Vilnius, Lithuania. Vilnius: Technika, 222-227.

Yudelson, J. 1999. Adapting Mccarthy's four P's for the twenty-first century, Journal of Marketing Education 21(1): 60-67. http://dx.doi.org/10.1177/0273475399211008

Zavadskas, E. K.; Turskis, Z. 2011. Multiple criteria decision making (MCDM) methods in economics: an overview, Technological and Economic Development of Economy 17(2): 397-427. http://dx.doi.org/10.3846/20294913.2011.593291

Zavadskas, E. K.; Turskis, Z.; Tamosaitiene, J. 2011. Selection of construction enterprises management strategy based on the SWOT and multi-criteria analysis, Archives of Civil and Mechanical Engineering 11(4): 1063-1082.

Romualdas GINEVIČIUS. Prof., Dr Habil, Head of the Department of Enterprise Economics and Management, construction engineer and economist. The author of more than 350 research papers and over 20 scientific books; Editor-in- Chief of the "Journal of Business Economics and Management" (located in ISI database "Web of Science") and the journal "Business: Theory and Practice". Research interests: organization theory, complex quantitative evaluation of social processes and phenomena.

Valentinas PODVEZKO. Doctor, Professor, Dept of Mathematical Statistics, Vilnius Gediminas Technical University. He is an author of more than 150 publications. Research interests: decisionmaking theory, expert systems, mathematical methods in modelling socio-economic, technological and engineering processes, hierarchical structuring of complex entities, sampling and forecasting models, simulation and stability of mathematical models.

Adomas GINEVIČIUS. Doctor, Head of Sales Development Department of TEO. Research interests: marketing, marketing structure optimization, marketing risk, expert estimations. 